\title{
10. CREATIVITY AND INNOVATION IN VISUAL ARTS THROUGH FORM AND SPACE HAVING SYMBOLIC VALUE
}

\begin{abstract}
Mihai - Cosmin Iaţeşen ${ }^{87}$
Abstract: The numerous plastic approaches of form in the $20^{\text {th }}$ century are characterized by creativity and innovation. Form, as expression of an artistic language, is the cause and effect for the cultural evolution of a particular spatial-temporal area. The invention of forms depending on the factors which will impose them in a particular socio-cultural context and location environment is not everything. The challenges of the act of creation are far more complex. For the art of the $20^{\text {th }}$ century, the role of the type of expression in visual or gestural language proved much more convincing and meaningful as to the data or phenomena occurring in immediate reality. The personality of the artist, his cultural character, his media coverage and exterior influences of his inner world, his preceding experiences and receiver's contacts in a specific area are the factors that influence the relation between the work of art and the audience against a particular spatial-temporal background. The psychological and sensory processes in works of plastic art are spatially configured in structures, which leads to self-confession. The artist filters the information and the elements of exterior reality through the vision of his imagination and power of expression specific to his inner self, and turns them into values through the involvement of his state of mind. Constantin Brâncuşi is the sculptor whose role was considered exponential as he revolutionized modern artistic vision by integrating and creating space-form relations through symbol. Throughout his complex work - the Group of Monumental Sculptures of Tg. Jiu, the artist renewed the language of the sculpture-specific means of expression, though archaic forms, by restoring traditional art. Archetypes often make reference to the initial and ideal form and they represent the primitive and native models composing it. Form attracts, polarizes and integrates the energy of the matter outside the human body, and art acquires a unifying function for the senses of our spirit. We identify the forms developed by the junction between fantastic forms, the figments of the imagination of artists who communicate deep human meanings. They invite us in a world of constructive forms and mysteries, truly innovative and elaborate creations, by underlying different directions in the compositional space with symbolic value.
\end{abstract}

Key words: art, creativity, innovation, form, space

\section{Introduction}

The diminution of the emotional emulation of the society has had significant consequences in the new globalization context occurring in the internet era. A particular form of "autism" has subjugated the society at the beginning of the $21^{\text {st }}$ century and threw it in an abyss dictated by an artificial climate, false professionalism, distorted reasoning and a game of fierce and unfair competition. When tackling the issues of creativity and innovation one also deals with the symbolic value which reflects on form and space, a binomial with particular importance in Contemporary Visual Arts. Light and color proved insufficient when rendering the human universe, for instance on stage. The

${ }^{87}$ Assistant PhD., "George Enescu“ National University of Arts from Iaşi, Romania, e-mail: iatecos@yahoo.com 
artists of the $20^{\text {th }}$ century were especially fond of form. Its creation through generalizations conferred by the symbolic function has led to new morphological expressions, which subsequently reached out beyond the traditional boundaries of arts.

The contribution of certain form perception stimuli to stage space structuring (light, shadow, movement, color, material) is reflected in the fact that our imagination continues to complement with new elements, regardless of one's personal experience, the incomplete reference about the world around us, which is specific to all symbols. The aspects focused on are individualized as a consequence of the general approaches of the language issues in plastic arts and scenography. Under these circumstances, the stage representation of the image created by the theatre of animation has become a challenge both for the artist in charge of the scenographic component and for the audience. "The universalistglobalist spread and the specificity of zonal cultures [...] the relation between tradition and contemporaneousness, between the cultural model emergence areas and peripheries" (Titu, 2003, p. 5) may be one of the causes of different form approaches in the $21^{\text {st }}$ century. The free expression of emotion cannot be encouraged and the aspiration to the total art ideal is completely unattainable in the absence of the concomitant development of the language means employed, under the umbrella of the dialogue between arts. The result may be a whole set of hermetic visions guided by eclectic obsessions, which influence artistic representations through form and space having symbolic value.

\section{Discussions}

Light, shadow, movement, color and material are important for stage space structuring and dynamic image reception themes. They may be analyzed by case studies and the impact on the receiver from the symbolic point of view. In Virgil Petrovici's opinion, the constructive-plastic solutions inhabiting the theatre stage space are connected nowadays by the transition from the moment of "synthesis of the arts to the union of expression means specific to different languages, like the ones expressed by gesture, word, line, color, rhythm and others". The esthetician-philosopher Constantin Aslan is the author of an interesting and concise classification, which places an emphasis on the complex history of the various hypostases of the form. The same topic was dealt with by the Polish theoretician Władysław Tatarkiewicz in his "History of Six Ideas". From the plastic-visual perspective, form ${ }^{88}$ is considered from a multitude of points of view and has undergone a series of transformations or adaptations to the period-specific manner in which space is perceived. The following distinction should be made between form and content: form ${ }^{89}$ is what outlines

\footnotetext{
${ }^{88}$ Shape-1. a set of elements able to outline and visually highlight any presence in space.*DEX http://www.dexro.ro; 2. the technical overall combination of these elements, the artist's choices in terms of material used of creation and the manner in which it is used" (Jones, 1997, p.)

${ }^{89}$ Shape - an organism living its own life, endowed with an unrepeatable legality in its singularity, independent in its autonomy, exemplary in its value which is inherent and yet open in its defined character which circumscribes an infinity, perfect in the harmony and unity of its coherence law, and made whole by the mutual
} 
and content is what is spatially outlined and may be visually perceived, the matter from which forms are built or cast, with the functions and meanings assigned to it.

Exact Sciences like Physics and Astronomy, computer processing of images, anticipation, imagination and creativity specific to Visual Arts have an exceptional contribution to the description of space and of its constitutive forms. When referring to Space, one cannot rule out the theme of the evolution of the Universe and of our Solar System. The opening of new inspiration horizons to artists has also materialized in the reflection of cosmic space in photography, due to the space exploration means and techniques breakthroughs in the physics field, more precisely in the optics field. A short trans-disciplinary excursion in the current research of space and space substance components enables one to infer, from the past of a universal whole, the primordial state of the forms which emerged as a result of multiple and successive constituting matter segregations. Biology researchers and specialists in computer processing of images have studied exotic geological formations, macro-cellular structural geometries, the growth and development processes of certain plant species. "Considerable space extension, an enlargement of its boundaries, occurs in two major directions: within the matter and towards the macrocosm". (Ailincăi, 2010, p. 37).

The matter of the universe is characterized by infinite movement and concentrates the celestial bodies (spherical forms, solid or gaseous globes), in unlimited numbers and infinite movement. The relations organized and structured in the space of our universe are perceived and understood through forms. The fundamental particles of the initial substance involved in a formation and transformation process relying on the universal attractive force - gravity are grouped in: galactic clusters, galaxies, stars, planets, satellites. There are forms that dissolve in space, which are generally defined by soluble substance. Each form in nature may decompose and recompose under the incidence of other factors and interactions between bodies. Nevertheless, artistic plastic forms are ever changing and redefining themselves in the plastic space, depending on the practitioner's cultural dimension and experience and on the audience's visual interpretation capacity.

Lucian Blaga, Mircea Eliade, Rudolf Arnheim are only some of the personalities who deciphered the depths of the mythical and psychological perception of polyvalent meanings and effects of important artistic creations. The works of artists like Wassily Kandinsky, Paul Klee, Lucio Fontana, Max Ernst, Victor Brauner, Picasso, Juan Miró, Salvador Dalí, Piet Mondrian allow multiple interpretations according to which "image is a window to a more subtle reality" (Ailincăi, 2010, p. 42). The transfigured artistic reflection of the cosmic space and of its constituent forms is well correlated with poetry or prose in literature, the symbol, metaphor or allegory being their coagulator against the background of general mythologies which acquire substantiality in what

agreement between the parts and the whole. (Luigi Pareyson Aesthetics and Theory of Formativity, Univers Publishing, Bucharest, 1977) 
concerns the content of the messages. The cosmic dimension of popular works of art, covering the myths of earth and human genesis, like for instance "Poor Dionysus" or Mihai Eminescu's "Evening Star", has inspired contemporary plastic artists like Sabin Bălaşa. "In the diversity of its exterior appearances, nature offers the structure of its organic development and expresses the fundamental laws which form emergence relies on" (Ailincăi, 2010, p. 37). Here are some of them: cosmic movement laws (form of the Earth and earth's relief); preservation laws (natural archetypal forms existing as species or man created forms); human physiological and psychological laws (behavioral forms of the human being). Numerous natural structures were interpreted and used in Visual Arts. Proportion approximation, form movement and transformation are related to the ability of the human being to perceive his or her surroundings based on certain landmarks. "Each landmark will have its own time, its own history, its own story..." (Ailincăi, 2010, p. 37). The artist filters the information and the elements of exterior reality through the vision of his imagination and power of expression specific to his inner self, and turns them into values through the involvement of his state of mind.

The relation between form and space depends on the movement stimulus in visual perception. Thus, when space is frozen, form becomes dynamic. This assumption may be proven in the works of the sculptor Jacques Liepchitz, with his sculptural works in which forms are developed based on rhythm and turbulent movements. The connection between three-dimensional forms and the earth through matter individualizes them in the whole mass (as parts of a big whole understood as substance). "Space becomes dynamic and only comes to life at ground level" (Ailincăi, 2010, p. 37), precisely due to its reflection in ourselves.

Form attracts, polarizes and integrates the energy of the matter outside the human body, and art acquires a unifying function for the senses of our spirit. We identify the forms developed by the junction between fantastic forms, the figments of the imagination of artists who communicate deep human meanings. They invite us in a world of constructive forms and mysteries, truly innovative and elaborate creations, by underlying different directions in the compositional space with symbolic value. An interdependence relation is established between natural forms and formal elements by a continuous metamorphosis process, under the influence of factors determining the transformations which occur in the Universe.

"Everything is form, life itself is a form" claims Honoré de Balzac. Henri Focillon refers to this comprehensive definition and infers his assumption about the inherent value of form by stating that "sign means something, whereas form is different, it contains forms itself". (Focillon, 1995, p. 7). The same author draws out attention to the fact that "forms require special analysis" (Focillon, 1989 , p. 13). When analyzing a visual creation, we refer either to its form, or to its content. Form involves the plastic elements used in the creation of a work, as well as the manner in which they are used overall, in the composition of the work. Thus, form is what we see directly. Content however is what we think that 
form expresses emotionally and intellectually. In a work of art we find symmetrical balance, logic composition, coherent volumes and sober colors. We will understand that this has a different meaning or content than a work using bright colors, random and unexpected brush strokes or indistinct or inarticulate volumes, meant to create a mere emotional effect.

Herbert Read argues that "the form of the work of art is nothing more than the configuration and structure of its components, its exterior and visible appearance" (Read, 1969, p. 38). The same author underlines the fact that "form is an impersonal concept, a theoretical or absolute concept" (Read, 1971, p. 79), whereas our human condition includes "various approximations of ideal forms" (Read, 1971, p. 203). As far as I am concerned, I would say that form as such embraces the personality of the person who conceives it from the deformed chaos of wooden pieces, closed or open mass of the modeling clay and of rocks, or the tumult of useful and easy to handle objects. Among the first tools of the primitive man, form emerged progressively, in time, until it exceeded the utilitarian goal of the adjusted object and subsequently became a work of art. Either we are aware of it or not, we all become sensitive to forms, regardless of the category to which they belong. According to ancient practical applications of sacred geometry in architecture, forms are true energy sources and from this point of view they have great transformation power on human consciousness and behavior (Feng Shuy concept).

The numerous plastic approaches of form in the $20^{\text {th }}$ century are characterized by creativity and innovation. The form, as expression of an artistic language, is the cause and effect for the cultural evolution of a particular spatialtemporal area. The invention of forms depending on the factors which will impose them in a particular socio-cultural context and location environment is not everything. The challenges of the act of creation are far more complex. For the art of the $20^{\text {th }}$ century, the role of the type of expression in visual or gestural language proved much more convincing and meaningful as to the data or phenomena occurring in immediate reality. The personality of the artist, his cultural character, his media coverage and exterior influences of his inner world, his preceding experiences and receiver's contacts in a specific area are the factors that influence the relation between the work of art and the audience against a particular spatial-temporal background. The psychological and sensory processes in works of plastic art are spatially configured in structures, which leads to self-confession.

In the avalanche of modernity specific to searches of new identities in the $20^{\text {th }}$ century, form ranges from contemporary to classical, from allegory to symbol, from eclectic to minimalistic. "As far as form is concerned, symbolists join the decorativistic searches specific to Art 1900, Art Nouveau" (Florea \& Székely, 2011, p. 676). Constantin Brâncuşi is the sculptor whose role was considered exponential as he revolutionized modern artistic vision by integrating and creating space-form relations through symbol. "The Group of Monumental Sculptures of Tg. Jiu" renews the language of the sculpture-specific means of expression, though archaic forms, by restoring traditional art. Archetypes often 
make reference to the initial and ideal form and they represent the primitive and native models composing it. "The first forms which man created were round forms - the circle, the stone disk with a hole in its middle, the sphere and the wheel" (Ailincăi, 2010, p. 42).

In order to understand the concept of form in sculpture and its evolution in time, one may analyze the evolution and meanings that this field has acquired nowadays in Visual Arts. The word plastic itself, which comes from the Greek plasein, means giving form and designates the art which models the body, being used with the same meaning as the word sculpture. In contemporary sculpture, form may have as its ideal the simplicity of reality and it depends to the highest extent on the conception about human value and about man's place in society and art. The metamorphosis of certain parts or of the whole female body coincides with the early days of the affirmation and emancipation of female personality in society. The elongated silhouettes of the characters, which remind us of some of Salvador Dali's paintings, determine the monumentality and spiritualization of the stylized figures, their ascension and detachment from the ground, by symbolizing the artist's own inner universe. "The spherical shape integrates a whole series of tree-like river structures, urban geometries, concavities or protuberances perceived as volumetric structures" (Ailincăi, 2010, p. 37).

Human culture began with symbol ${ }^{90}$ and myth $^{91}$. World culture preserved its spiritual unity and continuity through symbols inherited from ancient periods. Cosmologic symbolism originates in a symbolic thinking proper to ancient peoples and determined the development of a unitary morphology. The Sun and the Moon became symbols by means of myths present in many cults belongin to ancient civilizations. Among the most well-known myths, we may list: "Osiris, Baal, Mithra, Amun-Ra, Helios, Apollo" (Ailincăi, 2010, pp. 42-43). The authentic symbol is a sign of resonance in human consciousness, through the very importance and depth of its meanings, which always refers to the fundamental issues of life. In Visual Arts, symbols are systematically and incessantly resorted to in order to achieve memorable images. The name of a sign may be substituted by a symbol. Images or objects with magical or mystical evocative value may be considered symbols. Form and space with symbolic value predominate in the work of the famous Romanian sculptor Constantin Brâncuși. The Infinity Column, the Gate of Kisses and the Table of Silence and

\footnotetext{
${ }^{90}$ Symbol - the sign, insignia, object, image which conventionally or analogically represents or suggests an object, a notion, an idea or a feeling; in the science and technology field, by jotting certain notions, mathematical relations, operations or phenomena, the sign which represents or suggests a notion; in religion, literature and art symbols and symbolic expression are often resorted to. Memorable artistic images created by different forms of language and expression become suggestive of the time and space that they are suggestive of. An image may thus become a symbol due to its emotional, magical or mystical components. For instance, the "Creed" prayer is the symbol of faith in Christian religion. In literature, poetry and prose, it is frequently expressed by means of metaphors and symbols. In modern aesthetics, the term symbol defines a sign, which, within the limits of a determined convention, manages to transmit, allusively and hence incompletely from the visual or auditory point of view, information on a topic.*DEX - http://www.dexro.ro.

${ }^{91}$ Myth - story, legend, fairy tale; fabulous story which relies on the beliefs of ancient peoples, about the origin of the universe and natural phenomena, about gods and legendary heroes.
} 
the church located close to the axis of this ensemble are a series of absolute symbols for the Romanian ethnographic space and they obviously have archaic value. The ethnogenesis of Romanians is skillfully carved in stone, bronze or wood, in a remarkable way, by the most important artist of all times. Not only the sculptures themselves are symbols for Romania. Brâncuși's big themes and subjects are suggestive of a space and ethos ${ }^{92}$ that will impose themselves unlimitedly in world culture. Time thus becomes infinite due to the incontestable projection of form in space and to its acquiring symbolic and essential values. The information accompanying the symbols has surprising effects, impulses, energies and enthusiasm on the sensitivity of the human spirit. The symbol thus becomes the sign that helps preserve an optimal balance between content and expression, between spirit and matter, between intellect and emotions. Being genetically and functionally related to myth and religious rituals, the symbol is a world of imagination, much richer and more beautiful than the world surrounding us.

Symbols relate to the multitude of purely conventional and arbitrary signs in order to embrace the whole universe. They are accepted especially for practical reasons. True culture always tends to aim at polyvalent symbols with rich content and significant suggestive strength. The symbol has gone through several stages in cultural evolution. Exacerbated rationalism, scientism and reformism are only some of them. Its evolution phases are determined by the fact that symbol in general and archetypal symbol in particular are always an opening towards the world of mystery, beyond palpable realities. The signifier has always been, over the millennia, a true carrier of collective memory and has exercised a powerful and permanent modeling action on society and on humans, being a moral landmark, an axiological standard and an example of action. The specified qualities are proper, especially to those universal and ancient symbols, also called archetypes.

In stage representation, form and space have or are often vested with symbolic value. The Romanian scenographer Ion Truică applied, theorized and structured a whole series of issues that specialists in our field face. He found that "the combination of expression means will work based on energy, covert forces and mystery" (Truică, 2003, p. 96). The audience is thus captivated due to the energies transmitted by the image on stage created by the directors of the show. Theatrical magic, which many authors in this field speak about, relies on the force triggered by visual stimuli. Inner intensity and tension, as well as emotions may trigger a certain degree of sympathy, of attachment to an idea transposed on the stage, by keeping it or raising it, by the success of the approach, to the rank of landmark/model or standard. The expectations of the audience at the end of the play tend to focus increasingly on the atmosphere during the playing of the act on stage and to a lesser extent on the message that needs to be decrypted/interpreted. Time will tell whether the images on stage, created

\footnotetext{
${ }^{92}$ Ethos - a set of traits specific to a social group or to a period; moral physiognomy, morality; cultural specificity of a collectivity.
} 
especially by the dramatic character of the word and by the vitality of the human body, finally acquire a symbolic value. From the very beginning the scenographer may suggest the use of forms which make up a space having symbolic value, being stimulated also by the director's concept and the stylistic connections of the team. "The most original decorators suggest a confrontation between text and a plastic vision" (Truică, 2003, p. 97).

Starting with the creation of the character and ending with its plastic embodiment, the scenographer plays an arbitrary role. Without a specialized team, his role may be either minimized, or considered harmful. The world is guided by ideas which, by their synthesis and symbolic valorization in the artistic act, may lead to the formation of the collective mental state. We often witness nowadays hallucinating situations. The director has all the answers, the lighting technician exhibits his "talent" in choreography or scenography. "The actor has to be able to give life through sound and movement to those impulses on the fine line between dream and reality" (Truică, 2003, p. 98). The dialogue between the spheres of the means of expression in art may be beneficial as long as none of them crosses the line of common sense. The lack of involvement of a type of language (in the art of animation) will lead to unpredictable situations. Yet, this race for originality may have multiple risks and in the artistic field the observance of "recipes" has not proven beneficial. The show in the theratre of animation is a syncretic product, since scenography (a synthetic art located at the confluence of the other arts) has a decisive influence on its creation. The plurality of the means used to build representations is unequivocally based on creativity and innovation. The scenographer is a plastic artist endowed with a refined and sharp sense of observation, with a metaphorical vision of the text of the play. The plastic artist-decorator will find the forms or suggestive key for the chosen theme by studying the styles, symbols and mythology. The scenographer's knowledge is comprehensive and inexhaustible. They are related to the history of furniture stylistics, to the history of costume and to the representation of light (for the period). By corroborating them, he will define the color and character of the show by innovating the known solutions and means. If all these conventions are complied with, the space of the stage may become "a harmonious set of consonant forms" (Truică, 2003, p. 100).

\section{Conclusions}

Together with the director, the scenographer contributes to the achievement of the dramatic poetics of the stage representation. Many scenographers do not seem to be preoccupied with the entry into posterity of the scenographic image, since they are aware of the ephemeral nature of a show. The puppet, mask or costume is closely correlated with tradition, technique and culture in a geographical area. They have archetypal value and become symbols by form, light and color. In the theatre of animation, the puppet is not a mere stylized sculpture. With the help of the handling actor, it turns into symbol or metaphor. Initially achieved according to dogmas and subsequently by essentialization, thickening or abstraction, the mask, puppet or marionette 
becomes a means of expression and transmission of ideas or concepts in the stage representation followed by the actor and director.

The antagonism created by the rapidity of the technological progress overlapped on the conservatory attitudes determines an increase of the difficulty degree in what concerns the harmonization of traditional techniques with modern techniques from the plastic point of view. The agreement by which a common denominator may be set in the "dispute between scenographers, directors and handlers" exceptionally consists of the language used by plastic arts, since the sense of visual perception joins everybody to the audience. In our opinion, the fundamental elements of the constitution and functioning of the image are actually elements of the metamorphic structuring of the forms of representation on stage from a volumetric or pictorial perspective, identified by: line, form, color and volume. Nowadays, the role of video projections in scenography was amplified. The careful compositional association of the selected images, which depicts the props elements, objects making up the repertoire of the stylistic whole, may establish adequate relations within the bidimensional-tridimensional binomial, from the plane, through form, to volume and space. Scenography workshops outline true creativity, research and innovation media in Visual Arts, through form and space having symbolic value based on results characterized by strictness in the scientific and technical fields, and on the results in the artistic field created with great fantasy.

Light and shadow challenges the receiver to get familiar with the new language specific to visual arts of the $21^{\text {st }}$ century. The triggering of emotional reflexes and conceptual connections of creators and the troubled relation of form with space through symbol represents factors leading to the encoding of the genuine artistic message.

\section{Bibliography}

1. Ailincăi, C. (2000). Gramatica formelor vizuale [Grammar of Visual Arts]. București: PARALELA 45.

2. Ailincăi, C. (2010). Introducere în gramatica limbajului visual [Introduction to the Grammar of Visual Language]. Iași: Polirom.

3. Aslan, C. (2006). Paradigme ale artei şi frumosului, O perspectivă istorică şi sistematică [Paradigms of Art and Beauty, a Historical and Systematic Perspective] București.

4. Chevalier, J. Gheerbrant, A. (2009). Dicţionar de simboluri - mituri, vise, obiceiuri, gesturi, forme, figuri, culori, numere [Dictionary of Symbols - Myths, Dreams, Customs, Gestures, Forms, Figures, Colors, Numbers]. Iași: Polirom.

5. Constantin, P. (1977). Mică enciclopedie de arhitectură, arte decorative şi aplicate modern [Small Encyclopedia of Architecture, Modern Decorative and Applied Arts]. București: Editura Științifică și Enciclopedică.

6. Covătaru, D. (2005). Simbol şi obiect în sculptură [Symbol and Object in Sculpture]. Iași: Artes. 
7. Evseev, I. (1994). Dicţionar de simboluri şi arhetipuri cultural [Dictionary of Symbols and Cultural Archetypes]. Timișoara: Amarcord.

8. Florea, V. \& Szekely, G. (2011). Dicţionar universal de artă plastică [Universal Dictionary of Plastic Art]. București: Litera.

9. Focillon, H. (1989). Arta sculptorilor romanici - Cercetări cu privire la istoria formelor [The Art of Romantic Sculptors - Research on the History of Forms]. București: Meridiane.

10. Focillon, H. (1995). La vie des formes - Viaţa formelor şi Elogiul mâinii [The Life of Forms in Art and Praise of Hands]. București: Meridiane.

11. Grigorescu, D. (2003). Dictionarul Avangardelor [Dictionary of Avantgardes]. București: Editura Enciclopedică.

12. Jones, A. F. (1992). Introductiere în artă [Introduction to Art]. București: Lider.

13. Pareyson, L. (1977). Estetica şi Teoria formativităţii [The Aesthetics and Theory of Formativity]. București: Univers.

14. Petrovici, V. (1974). Lumină și culoare în spectacol [Light and Color in Shows]. București: Albatros.

15. Petrovici, V. (1976). Tehnica iluminatului artistic [Artistic Lighting Technique]. București: Editura Technică.

16. Prut, C. (2002). Dicţionarde Artă modernă şi contemporană [Dictionary of Modern and Contemporary Art]. București: Editura Enciclopedică.

17. Read, H. (1969). Semnificaţia artei [The Meaning of Art]. București: Meridiane.

18. Read, H. (1971). Originea formei în artă [The Origins of Form in Art]. București: Universul.

19. Sendrail, M. (1983). Sensul formelor - Înţelepciunea formelor [Meaning of Forms - Wisdom of Forms]. București: Meridiane.

20. Shepherd, R. \& Shepherd, R. (2007). Dicţionar cu 1000 de simboluri Semnificaţia formelor în artă şi mitologie [1,000 Symbols: What Shapes Mean in Art and Myth]. Oradea: Aquila'93.

21. Titu, A. (2003). Experimentul în arta românească după 1960 [Experiment in Romanian Art after 1960]. București: Meridiane.

22. Truică, I. (2003). Teoria scenografiei [Theory of Scenography]. Iași: Junimea. 